\title{
STUDIES ON THE POPULATION STRUCTURE OF ZOOPLANKTON IN THE KOTMALE RESERVOIR
}

\author{
SWARNA PIYASIRI ${ }^{*}$ and W.P.N. CHANDRANANDA ${ }^{2}$ \\ ${ }^{\prime}$ Department of Zoology, University of Sri Jayewardenepura, Nugegoda, \\ ${ }^{2}$ Department of Zoology, The Open University, Nawala, Nugegoda.
}

(Received: 29 October 1996; accepted: 03 July 1998)

\begin{abstract}
Plankton samples were collected from Kotmale reservoir, at approximately monthly intervals from August 1990 to August 1991. Investigations were focusecl on species composition, seasonal variation, vertical and horizontal distribution and the size class distribution in the population structure of zooplankton. Two species of cyclopoids, two species of calanoids, nine species of cladocerans and sixteen species of rotifers were recorded. Among these, the most abundant species during the study period were Mesocyclops sp. Phyllodiaptom us annae, Ceriodaphnia cornuta, Keratella tropica, Filina longiseta, Brachionus caudatus and Tricocercu similis. A location at the deepest region of the reservoir closer to the dam was selected as a representative station to investigate the vertical distribution of zooplankton. At this location, the vertical distribution patterns of all the zooplankton were almost similar throughout the year. As this location is situated at the down stream region of the river, it was expected to contain most of the zooplankton of the reservoir. The horizontal distribution of zooplankton did not show much variation. The nauplii stages and cyclopoids showed highest abundance in the population of zooplankton. However, during most of the months, the adult stages of calanoids and cladocerans were highly abundant.
\end{abstract}

Key words: Cyclopoids, calanoids, cladocerans, rotifers, seasonal variation, population structure, zooplankton.

\section{INTRODUCTION}

Kotmale reservoir is located at an elevation of 640 to $762 \mathrm{~m}, 2100$ feet above sea level with a geographical position of $7^{\circ} 03^{\prime}$ to $7^{\circ} 05^{\prime} \mathrm{N}$ and $80^{\circ} 36^{\prime}$ to $80^{\circ} 41^{\prime} \mathrm{E}$. The morphometric features of the reservoir could be summarized as follows: surface area $=6.5 \mathrm{~km}^{2}$, maximum depth $=90 \mathrm{~m}$, volume $=174 \mathrm{mcm}$, mean depth $=26.8 \mathrm{~m}$, maximum length $=6.8 \mathrm{~km}$ and maximum width $=1.41 \mathrm{~km}$.

Kotmale reservoir is the uppermost reservoir of an interconnected reservoir chain which is fed by a large number of tributaries from its catchment. The inlets of the catchment could therefore often influence the species diversity, seasonal variation and the population structure of the zooplankton in the reservoir. 
Much work has been already done on zooplankton in the water bodies of Sri Lanka. According to Fernando ${ }^{1.2}$ the limnetic zooplankton of Sri Lanka are typically tropical and poor in species diversity ${ }^{2}$ and those with large body sizes were absent or rare in tropical waters. ${ }^{2}$ Species composition in various water bodies of Sri Lanka is markedly different during different seasons of the year," which may be both short and long-term..$^{4,5}$ Work on the composition of zooplankton species in Mahaweli reservoirs, ${ }^{6-10}$ indicated that the zooplankton component was represented by copepods, cladocerans \& rotifers in the upland Mahaweli reservoirs and that the species richness of copepods was less than that of the rotifers and cladocerans.

The objective of the present work is to construct a complete picture of the species composition, seasonal fluctuations and the vertical and horizontal distribution patterns of the zooplankton and to describe the population of the zooplankton in the reservoir during the period of investigation from August 1990 to August 1991.

\section{METHODS AND MATERIALS}

Sampling procedure: Fig.1 illustrates the locations of the sampling stations. St1 closer to the dam, is the deepest region in the reservoir and it was selected as a suitable location to investigate the vertical distribution pattern of zooplankton due to the following reasons: (1) As this location is situated at the down stream region, due to the direction of water flow, it was expected that this location would contain most of the representative zooplankton types of the reservoir. (2) As this is the deepest part of the reservoir its water level remains at a considerably higher level, even during severe droughts. (3) Therefore it allowed the comparison of the vertical distribution patterns of zooplankton during both high and low water levels. (4) Thus the results were comparable throughout the study.

For horizontal sampling, 10 locations (St1, St2, St3, A, B, C, D E, F \& G) were selected from the dam site to the upstream region as illustrated in Fig. 1.

Vertical distribution: At major station 1, zooplankton samples were collected by filtering vertical columns of water from varying depth intervals from $0-10 \mathrm{~m}$, $10-20 \mathrm{~m}, 20-30 \mathrm{~m}$ etc. using a clesing type net with $50 \mu \mathrm{m}$ mesh size which filtered $0.2011 \mathrm{~m}^{3}$ of water.

Sampling was done from $0900 \mathrm{~h}$ to $1400 \mathrm{~h}$, at monthly intervals for a period of one year from August 1990 to August 1991. Samples collected were transferred into sampling bottles and fixed in 5\% formaline and transported to the laboratory for further investigations. 


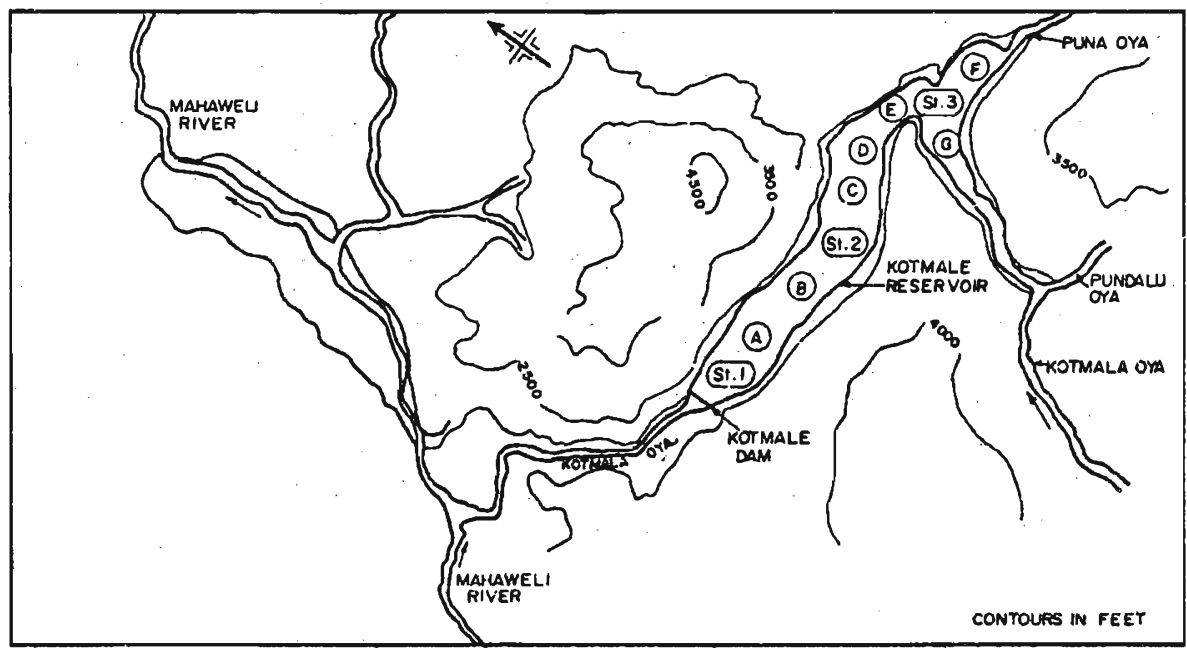

Figure 1: Kotmale reservoir with the locations of sampling. St1, indicates the location. where the sampling was done along the vertical profile of the water column. At St 2, St $3, A, B, C, D, E, F \&$ G stations, sampling was done at the surface \& at $10 \mathrm{~m}$ depths.

Horizontal distribution: As the euphotic limit of the reservoir was less than $10 \mathrm{~m}$ as indicated in Piyasiri, ${ }^{11,12}$ for investigations on horizontal distribution, sampling was done at the top $10 \mathrm{~m}$-epilimnetic region where the zooplankton was highly abundant.

Samples collected in the field were transferred into sampling bottles and fixed in $5 \%$ formaline and transported to the laboratory for identification and enumeration.

Analysis of samples: All the plankton samples were diluted upto $100 \mathrm{ml}$. Then 5 random sub samples_each representing $1 \mathrm{ml}$ with a coefficient of variation of 0.1 -0.35 ) were used to analyse the zooplankton. For identification of zooplankton in the samples, keys of Streble \& Krauter $^{13}$ were used. Different types of zooplankton in each sub sample were counted using a Sedgewick Rafter counting chamber.

Life cycle stages and size class distribution: To study the population structure of the zooplankton community, the total lengths of different stages were measured in $80 \%$ of the counted individuals using an eye piece micrometer.

There were Nauplii of various stages with body lengths ranging from 0.09 to $0.33 \mathrm{~mm}$. N1 \& N6 stages were identifiable and belonged to the size ranges of 0.09 to $0.12 \mathrm{~mm}(\mathrm{~N} 1) \& 0.31$ to $0.33 \mathrm{~mm}$ (N6) respectively. As it was difficult to distinguish N3 to N5 stages, they were collectively considered in the size range 
of 0.13 to $0.31 \mathrm{~mm}$ in the population structure. The copepodite stages $\left(\mathrm{C}_{1}\right.$ to $\left.\mathrm{C}_{5}\right)$ were identified using their morphological features and were categorized into different size classes accordingly. Ceriodaphnia cornuta were categorized into three size classes, which represented the embryonic stage (the smallest size class), the nymphs and the adults. For Rotifera, it was impossible to identify the stages and therefore analysis of life cycle stages was not attempted. For data analysis on size class distribution of plankton, related to their stages, zooplankton collected from epilimnetic waters along the horizontal axis of the reservoir was considered.

\section{RESULTS}

\section{Seasonal fluctuation of zooplankton}

Table 1 illustrates the richness of species in Kotmale reservoir. Sixteen species of rotifers, nine species of cladocerans, and three species of copepods were recorded during the present investigation. Fig. 2 illustrates the monthly variation in percentage occurrence of Cyclopoida, Calanoida, Cladocera \& Rotifera of the epilimnetic waters of the reservoir. Copepods made a significant contribution to zooplankton population (Fig. 2). Calanoids were the least abundant and cyclopoids and rotifera dominated the population throughout the investigation. Cladocera occurred in fairly high percentages throughout the investigation.

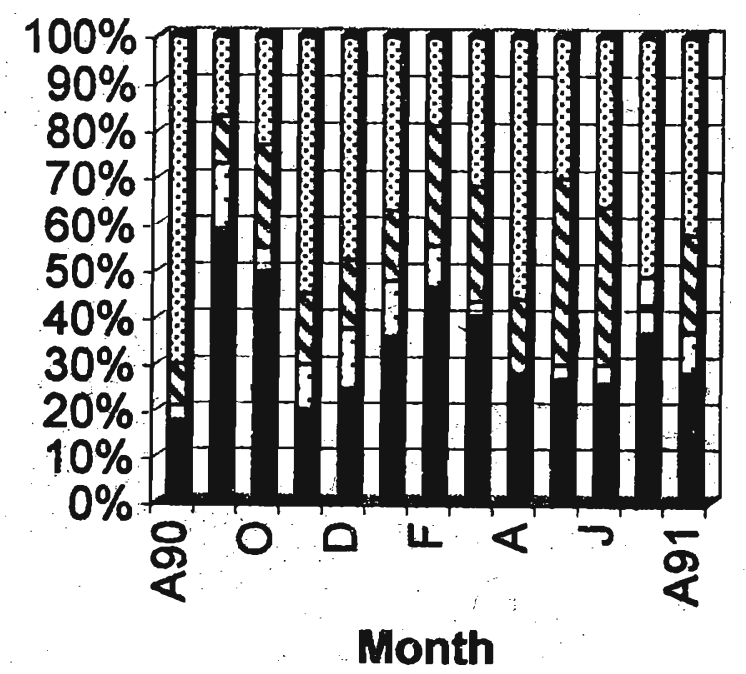

Cyclopoida @ Calanoida \$Cladocera 8 Rotifera

Figure 2: Percentage composition of Cyclopoida, Calanoida, Cladocera \& Rotifera in the zooplankton community of the epilimmetic waters of Kotmale reservoir. For this analysis, samples collected from all the locations from surface to $10 \mathrm{~m}$ depths during the investigation period were considered. 
Table 1: Zooplankton in Kotmale reservoir during 1990 to 1992 investigation period. All the samples collected during the study period were analyzed.

No. Rotifera No. Cladocera No. Copepoda

\begin{tabular}{|c|c|c|c|c|c|}
\hline & Family Brachionidae & & Family Daphnidae & & \\
\hline 1 & Brachionus caudatus & 1 & Ceriodaphnia cornuta & 1 & Mesocyclops sp. \\
\hline 2 & Brachionus falcatus & 2 & Daphnia lumholtzi & 2 & Thermocyclops crassus \\
\hline 3 & Brachionus angularis & 3 & Diaphanosoma aspinosum & 3 & Tropodiaptomus australis \\
\hline 4 & Brachionus calyciflorus & 4 & Diaphanosoma modigliani & & \\
\hline 5 & Brachionus forficula & & Family Moinidae & & \\
\hline 6 & Anuraeopsis fissa & 5 & Moina micrura & & \\
\hline \multirow[t]{2}{*}{7} & Keratella tropica & & Family Chydoridae & & \\
\hline & Family Triccocercidae & 6 & Chydorus eurynotus & & \\
\hline 8 & Tricocera similis & 7 & Alona sp. & & \\
\hline \multirow[t]{2}{*}{9} & Tricoceraca birostris & & Family Bosbinidae & & \\
\hline & Family Filinidae & 8 & Bosmina sp. & & \\
\hline 10 & Filina opoliensis & & Family Macrothricidae & & \\
\hline \multirow[t]{2}{*}{11} & Filina longiseta & 9 & Macrothrix sp. & & \\
\hline & Family Hexarthridae & & & & \\
\hline 12 & Hexathra sp. & & & & \\
\hline 13 & Asplanchna $\mathrm{sp} 1$ & & & & \\
\hline \multirow[t]{2}{*}{14} & Asplanchna sp2 & & & & \\
\hline & Family Lampryidae & & & & \\
\hline 15 & Lecane $\mathrm{sp} 1$ & & $\therefore$ & & \\
\hline 16 & Lecane sp2 & & & & \\
\hline
\end{tabular}

Fig. 3 illustrates the monthly fluctuations in the abundance of different species of Cladocera, Rotifera and Copepoda at the surface epilimnetic waters of the reservoir. C. cornuta was the dominant species of the Cladocera population during most months whereas all the other cladoceran species appeared in low densities. There were two morphological forms in C. cornuta population. ${ }^{7}$

A thick bloom of Microcystis aeruginosa covered the Kotmale reservoir during the latter part of 1991 from Sept. to December $1991 .{ }^{12}$ During this period, it was found that the $C$. cornuta with small body sizes were dominating the Cladocera population of the reservoir.

D. lumholtzi was the largest Cladocera (mean length $=1.38 \mathrm{~mm} \mathrm{SD} \pm 0.12$ ) in the range of $1.98 \mathrm{~mm}$ to $2.34 \mathrm{~mm}$. It had two morphological forms. The less common one was with a thin long spine-like process on the head region and a thin body while the common form had much shorter and stouter process on the head 


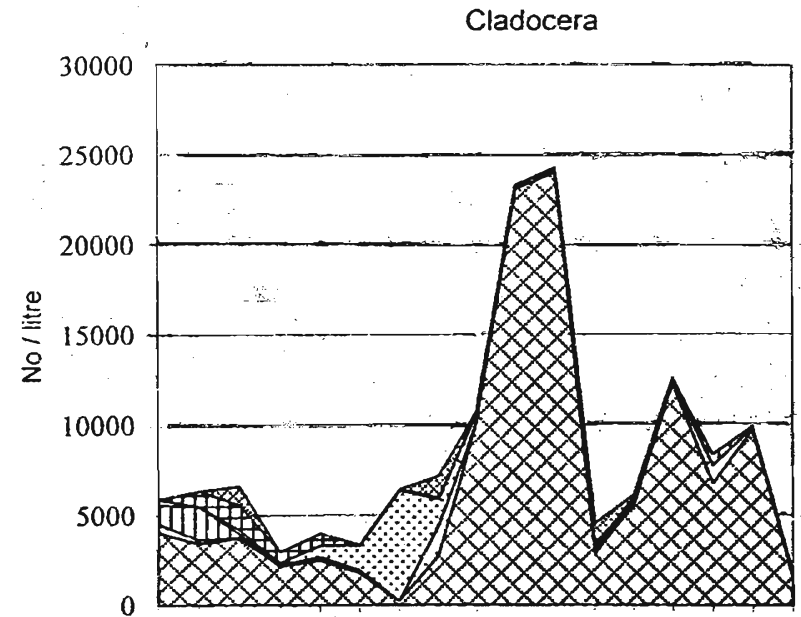

\section{Moina $s p$ \\ 田D lumholtzi \\ O Curynotus}

ㅁ] $D$ aspinosum

$\square D$ modigliani

凶C cornuta

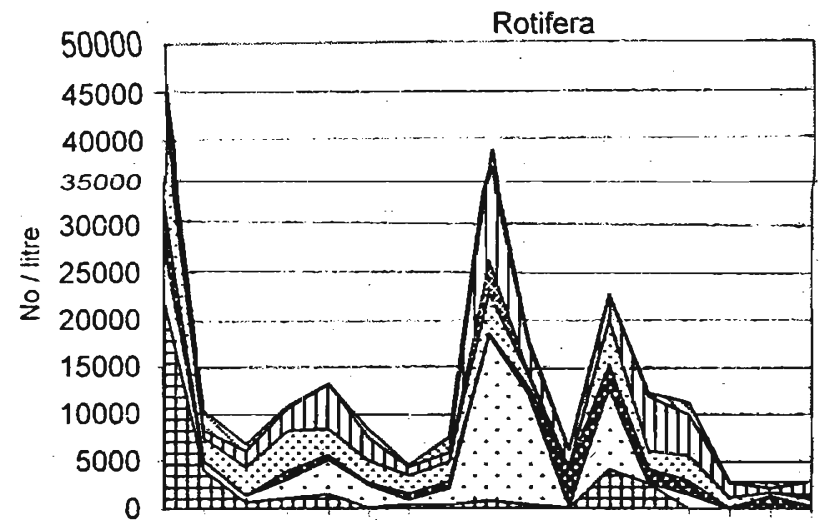

Asplanchna sp

口] Keratella tropica

ro longiseta

응 opoliensis

$T$ birostris

$\square T$ similis

田 $B$ caudatus

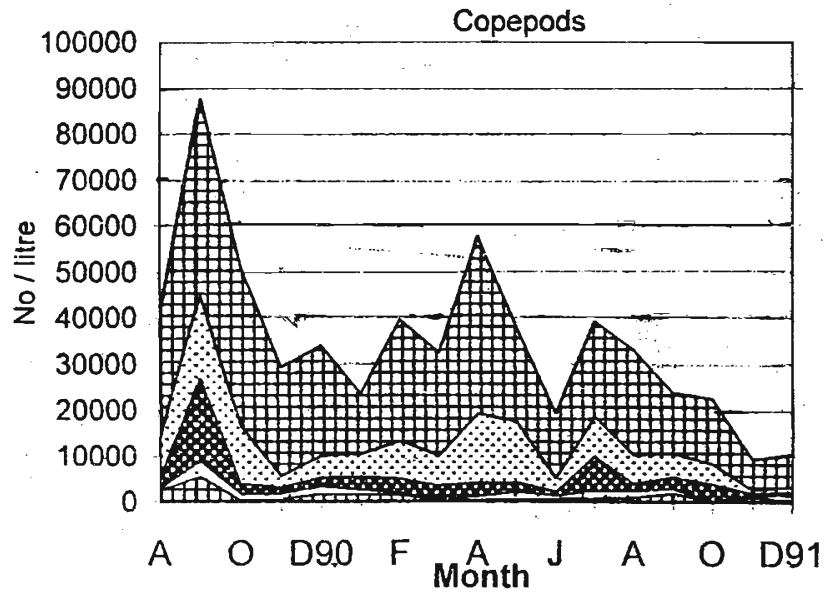

Figure 3: Seasonal variation and abundance of different species of Calanoida, Rotifera $\&$ Copepoda (as Number per litre) at the epilimnetic waters of the Kotmale reservoir. 
and its body was stout. C. eurynotus species was generally abundant from December 1990 to March 1991. Other Cladocera species: Moina species, D. aspinosum and $D$. modigliani were found in low numbers during this study.

As shown in Fig. 3 the most abundant rotifer species was B. caudatus, $F$. opoliensis, K. tropica, T. birostris and Asplanchna species. The peaks in the rotifer population were observed from Aug. to Sept. 1990, April - May 1991 \& July to Sept. 1991.

As illustrated in Fig.3 the copepods population was dominated by Nauplii stages throughout the investigation. Copepodite stages of cyclopoids (Cyclo S) also made a significant contribution. Considering the adults, cyclopoids (Cyclo A) dominated over the calanoids (Cala A). Copepodid stages of calanoids (Cala S) were low in number throughout the investigation period.

\section{Distribution}

\section{Vertical distribution during high water level}

Fig.4 A illustrates the general vertical distribution pattern of zooplankton at St1 recorded in August 1990 (when reservoir water level was high closer to the dam). When the reservoir water level was high, most of the zooplankton types were distributed throughout the water column. B. caudatus and $F$.opoliensis densities were high even at 30 to $40 \mathrm{~m}$ depths. All the other rotifer species showed more or less uniform distribution along the water column.

Out of the cladocerans, C. cornuta was dominant from 30 to $40 \mathrm{~m}$ depth range whereas $D$. aspinosum density was high upto 10 to $20 \mathrm{~m}$. C. eurynotes and D. modigliani were more or less uniformly distributed along the vertical profile.

Out of the copepods, Cyclopoid copepodites indicated highest densities from 20 to $40 \mathrm{~m}$ whereas all the other copepods were approximately uniform along the water column. Nauplii stages were strikingly high from 20 to $40 \mathrm{~m}$.

Eggs and nymph stages of cladocerans did not show any similarity to the vertical distribution pattern indicated by the adults and other stages of zooplankton. The highest accumulation of zooplankton from $20 \mathrm{~m}$ to $40 \mathrm{~m}$ depth range was the general tendency of the vertical distribution pattern of zooplankton in Kotmale reservoir.

\section{Vertical distribution during low water levels}

Fig. 4B illustrates the vertical distribution pattern of zooplankton at the dam region in October 1990, (at low reservoir water level when power generation 


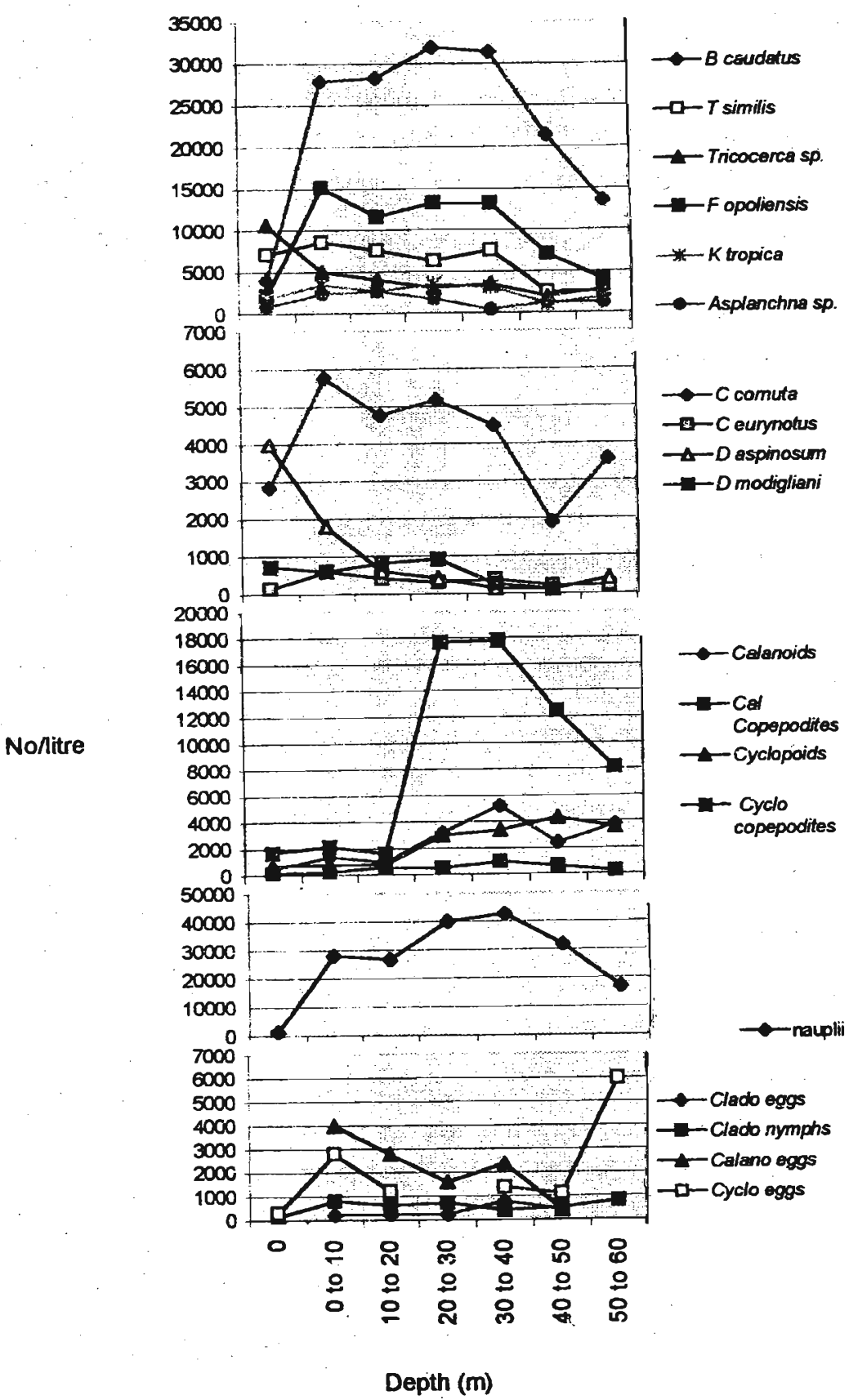

Figure 4A: General vertical distribution pattern of zooplankton at St1 recorded in August 1990, when the water level of the reservoir was high closer to the dam. 


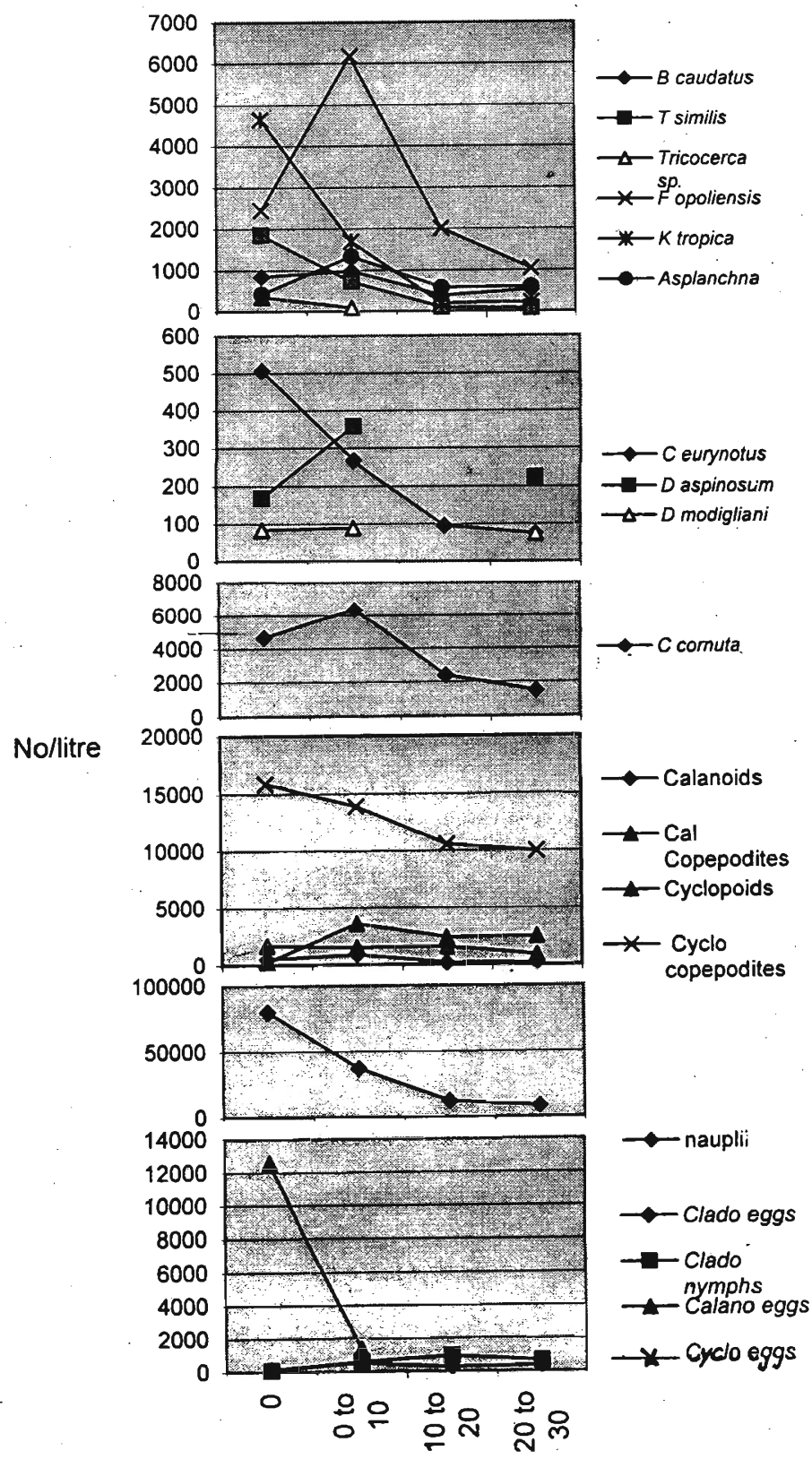

Depth (m)

Figure 4B: General vertical distribution pattern of zooplankton at St1 recorded in October 1990 when the water level of the reservoir was low. 
was limited). This pattern shows that the zooplankton was high in abundance from the surface to $10 \mathrm{~m}$ depths and decreases in density with increasing depth. This was the general trend found in the vertical distribution pattern of zooplankton at St1 during the other months of the investigation period during low reservoir water levels.

\section{Horizontal distribution}

Fig. 5 illustrates the horizontal distribution of copepods, cyclopoids, $C$. cornutc and Keratella sp. at the epilimnetic water layer from the dam site to the upstream region along the longitudinal axis of the reservoir. Population densities of all these forms were generally low at the dam site. However at the middle part of the reservoir, highest abundance of these types were recorded. At the upstream region their abundance was generally high. There was no variation in horizontal distribution pattern of Nauplii at the surface and at $10 \mathrm{~m}$ depths. For all the samples collected during the investigation period at ten sites, the mean number of Nauplii per litre present at the surface was $32.2 \mathrm{SD} \pm 13.6, \mathrm{CV}$ 0.42 and at $10 \mathrm{~m}$ depths it was $35.3, \mathrm{SD} \pm 17.95$, CV 50. As illustrated in Fig.5, the cyclopoids were observed throughout the reservoir with a mean abundance of 12.78 per litre, $\mathrm{SD} \pm 9.5, \mathrm{CV} 0.74$. During the investigation period, they were more abundant in St2, St3, and at F locations. There was no difference in the horizontal distribution of C. cornuta, but their abundance was slightly higher in St3 than the other stations on most of the sampling occasions.

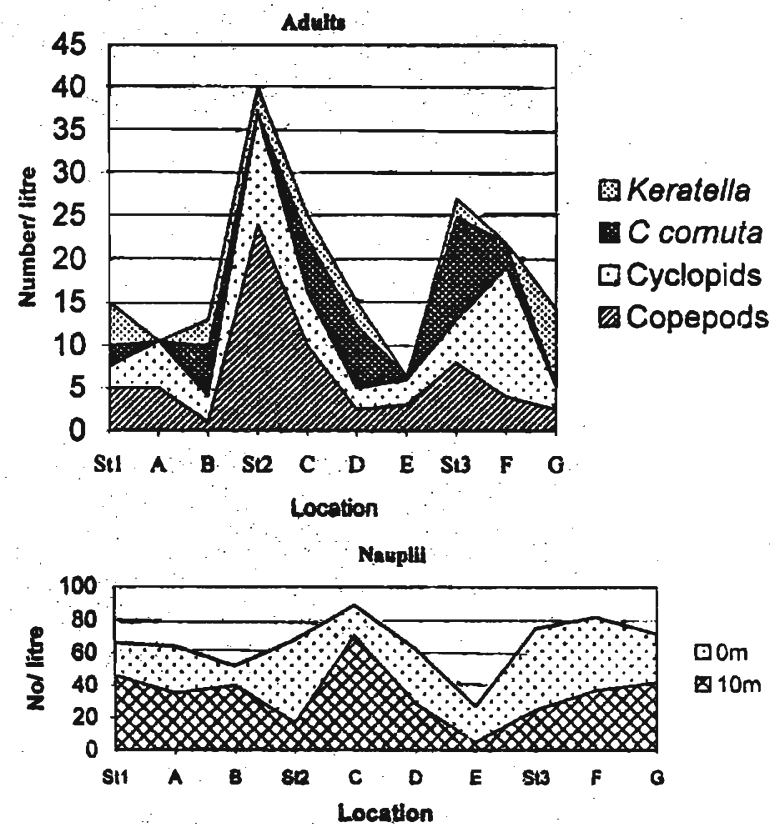

Figure 5: Abundance of Keratella, C. cornuta, Cylopoids, copepods (as no. per litre) \& Nauplii (number per litre) along the horizontal axis of the reservoir. Analysis was based on the samples collected from all the stations at the surface to $10 \mathrm{~m}$ depths. 


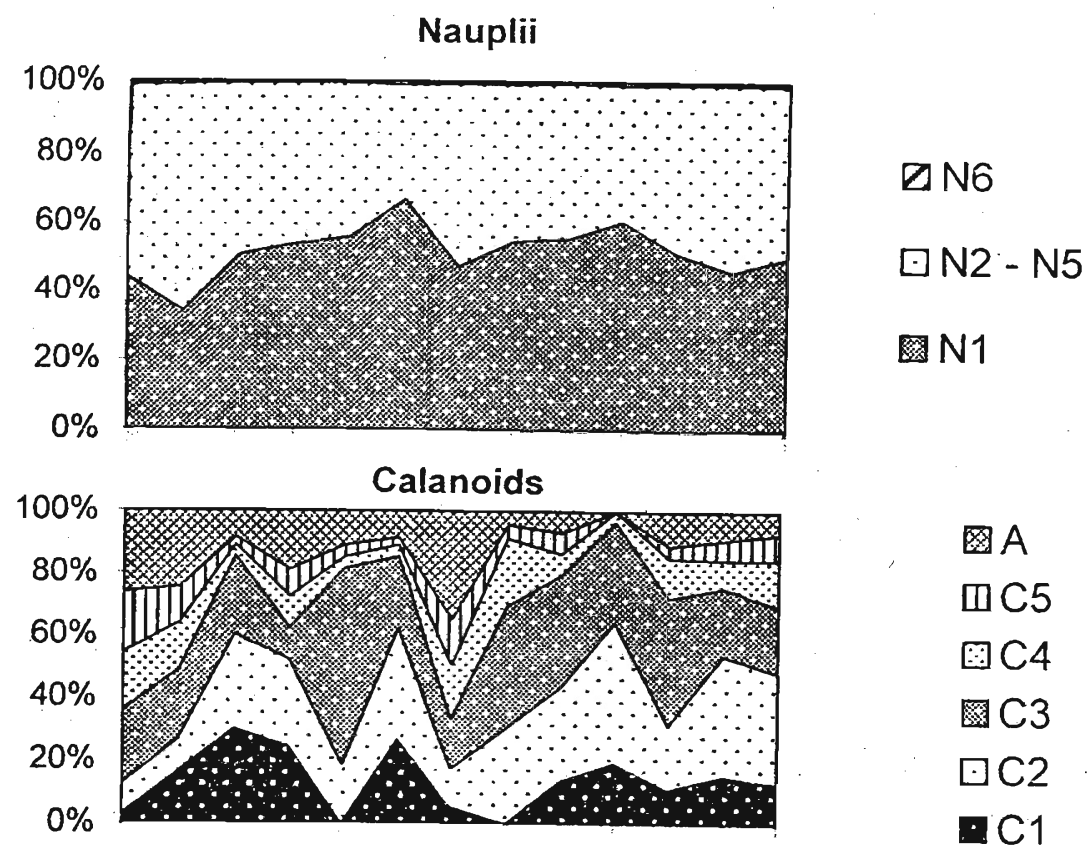

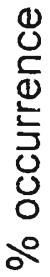

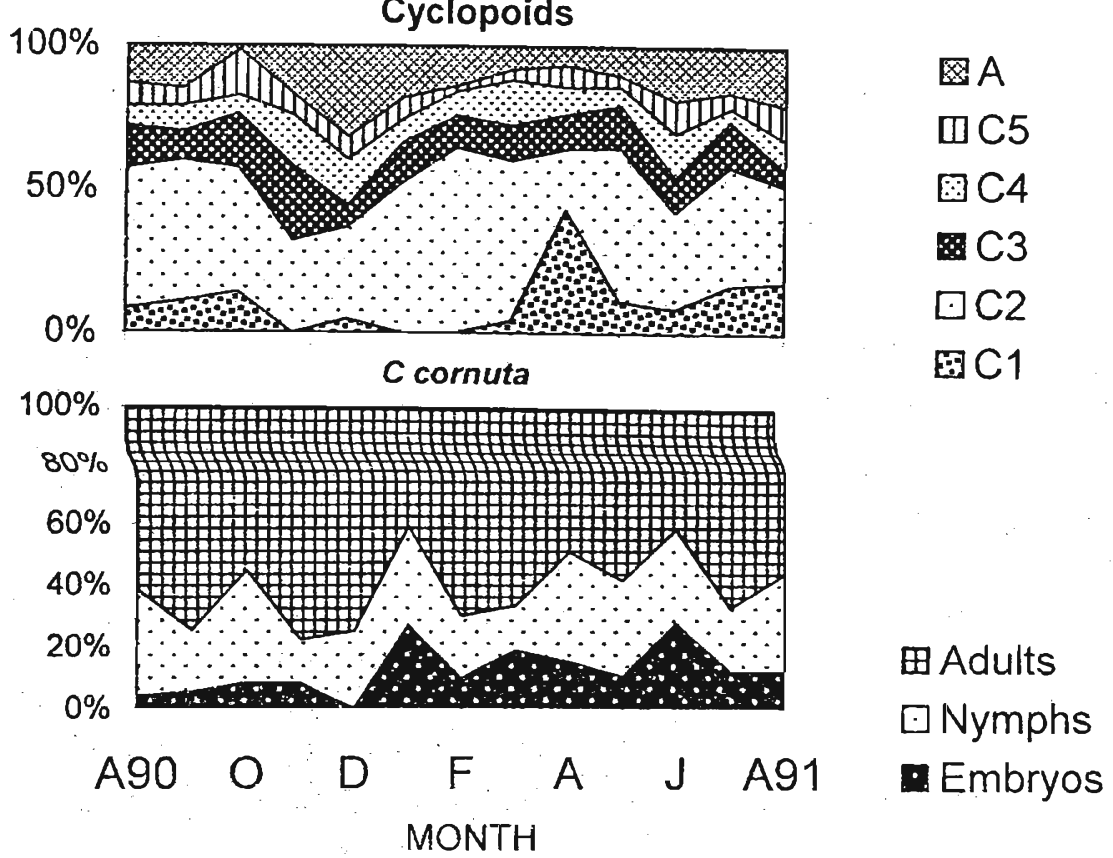

Figure 6: Seasonal variation of occurrence of Nauplii, Calanoids, Cyclopoids C, cornuta at the surface to $10 \mathrm{~m}$ depth; at the epilimnetic waters of the reservoir during the investigation period 


\section{Population structure}

\section{Nauplii}

Fig.6 illustrates the distribution of Nauplii stages of Copepoda in the reservoir. Data from all sites at surface to $10 \mathrm{~m}$ depths, (horizontal sampling locations) were utilized to compare these results. Plankton population was composed of Nauplii of various stages and their body lengths varied between 0.09 to $0.33 \mathrm{~mm}$. The smallest size range (N1 stage) was $0.09-0.12 \mathrm{~mm}$ which comprised $34 \%-67 \%$ (mean of $50.6 \%, \mathrm{SD} \pm 0.84, \mathrm{CV}=0.017$ ) of the Nauplii stages. The total number of individuals decreased gradually with increase of the size range (with the stage). Comparatively few numbers of individuals were present in the higher size classes of $0.31-0.33 \mathrm{~mm}$ which represent the N6 stage (Fig.6). From Oct. - Nov. 1990 \& Feb .- March 1991 large Nauplii (N6) with length classes of 0.31 to $0.33 \mathrm{~mm}$ were present in the population, but were very few in number and negligible compared to other stages as indicated in Fig.6.

\section{Copepodite stages of cyclopoids}

In the copepod population, the copepodite stages of cyclopoids and calanoids were identifiable. The smallest Cyclopoid copepodite stage (C1 stage) recorded had a body length of $0.27 \mathrm{~mm}$ and the smallest calanoid copepodite stage had a length of $0.36 \mathrm{~mm}$.

Fig 6 illustrates the distribution of different copepodite stages of cyclopoids in different months collected from epilimnetic waters of the entire reservoir. The increase in their body length is a measure of their stage. Different copepodite stages belonged to different size class ranges as $\mathrm{C} 1: 0.27-0.35 \mathrm{~mm}, \mathrm{C} 2: 0.36$ 0.44mm, C3: $0.45-0.53 \mathrm{~mm}, \mathrm{C} 4: 0.54-0.62$, and C5: $0.63-0.71 \mathrm{~mm}$ and the Adults: 0.72 - 1.34. Early copepodite stages were high in number compared to that of Nauplii of the final stages, which indicate molting of Nauplii to the copepodite stages. In May 1991, the lowest size class $(0.27$ to $0.35 \mathrm{~mm}$ ) became most abundant and in the, same month lowest water level ( $35 \mathrm{~m}$ at dam site) was recorded with high temperature which could be considered as favourable conditions for hatching of eggs. During this period, abundance of Nauplii and copepodite stages were also fairly high. However the density of the adult cyclopoids decreased to low levels. The population of copepodite stages decreased gradually with the increase in body size (stage). The adults (body size $>0.63 \mathrm{~mm}$ ) were always numerically lower than the copepodite stages. During high water levels, the adults were numerically high in the population.

In Aug. to Sept. 1990, Oct. to Dec. 1990 and in March 1991, the adults of calanoid population were more numerous. This situation was different from cyclopoids population where copepodites dominated throughout the investiga- 
tion period. However both copepodite stages and adults were lower in numbers in calanoids than that of cyclopoids throughout the year. According to Fig. 6 there was a fluctuation in percentage contribution of different stages with different size classes to the population of calanoids. Percentage of C4, C5 and adults of calanoids were less than the smaller copepodite stages of the population.

\section{Cladocera}

As illustrated in Fig. 2, cladocerans contributed significantly to the zooplankton community of the epilimnetic waters of the reservoir during most months of the year.

C. cornuta dominated the samples throughout the study (Fig.3) except in Feb .1991. As illustrated in Fig.6, Cladocera community of the epilimnetic waters of the reservoir contained various stages of $C$. cornuta (with different size class ranges). There were rare occasions where larger individuals with a body length between 0.87 to $0.90 \mathrm{~mm}$ were recorded. The individuals belonging to the first size class range were considered as embryos (not properly developed) and generally they were present in low numbers. The second size range $(0.33$ to $0.41 \mathrm{~mm}$ ) which was considered as nymphs, were abundant in the epilimnetic waters. The percentage abundance of $C$. cornuta adults was higher in the population than the nymphs and the embryos in the limnetic zone. The population structure and the dominant size class varied monthly.

\section{DISCUSSION}

During the present investigation, twenty eight zooplankton species were found in the epilimnetic waters of the Kotmale reservoir. The highest number of species was found in Rotifera in which sixteen species were recorded, whereas it was low in Copepoda and Cladocera. Fernando ${ }^{14}$ has also found similar results for three taxonomic groups of zooplankton present in the water bodies of Sri Lanka. Out of the three major taxonomic groups, the Copepoda and Rotifera have dominated the zooplankton population at the epilimnetic waters of the reservoir. Piyasiri \& Jayakody ${ }^{6}$ for Victoria reservoir \& Pathmalal \& Piyasiri ${ }^{8}$ for Randenigala have also found copepods as the most dominant zooplankton type as in the present case. Rajapakse \& Fernando ${ }^{15}$ have found copepods in high percentages in the littoral zones of the water bodies of Sri Lanka. The calanoids population was comparatively smaller than the cyclopoids population in the epilimnetic waters of the reservoir. Large number of copepodite stages than the adults represented calanoids and cyclopoids. Vijverberg ${ }^{16}$ has found copepodite I and II stages and the adults as the most abundant stages in the zooplankton population of temperate lakes. In the present study, as illustrated in fig. 3, copepodite I, II \& III stages and the adults were the most abundant in the calanoids population of the epilimnetic waters. In cyclopoids population (Fig. 3), the copepodite stage II was the most dominant compared to other stages. 
Nauplii of the crustaceans have dominated the copepod population of the Kotmale reservoir. ${ }^{7}$ The crustaceans Nauplii were most noticeable among zooplankton in Colombo lake. ${ }^{17}$

The Nauplii density found in the epilimnetic waters of the reservoir indicated very low densities of late Nauplii stages (N6) compared to the smaller stages. This could be related to many reasons. The development time of the 6 th Nauplii stage to adult may be very fast under warmer conditions and also due to their large sizes, they may become a prey for larger invertebrates and fish larvae which cause the high mortality rates.

C. cornuta was the most abundant Cladoceran type in the epilimnetic waters of the Kotmale reservoir. Fernando ${ }^{1}$ also found $C$. cornuta as a dominant limnetic species and according to Rajapakse \& Fernando, ${ }^{15}$ it is found in every habitat type. C. cornuta is the most dominant Cladocera in the Victoria reservoir as in the present study. ${ }^{11}$

Presence of two morphological forms in C. cornuta has been previously recorded. ${ }^{18.19}$ Both had equal body sizes but one was with tiny protuberances on the head region and a small eye and the other was without any protuberance but with a large eye. ${ }^{18,19}$ Rajapakse \& Fernando ${ }^{15}$ also described a cyclomorphosis in C. cornuta with horn like projections on the head and pointed beak like rostrum with similarities to the forms found in the Kotmale reservoir. The unhelmeted form of $D$. lumholtzi $i^{20}$ was not recorded in the Kotmale reservoir and the two morphological types found in the Kotmale reservoir were with processes on the head.

As mentioned earlier, it is a known fact that the general trend of the body sizes of zooplankton in tropical waters is smaller sizes than that of temperate waters. Vidal ${ }^{21}$ based on his detailed ecophysiological experimental work has explained body size related patterns of geographical and vertical distribution in species of zooplankton. That is, oligotrophic tropical and sub tropical regions with deep thermoclines are characterized by the dominance of small sized species, while richer temperate and boreal regions with shallower thermoclines are noted for the abundance of larger species. In a fresh water lake in the Netherlands, ${ }^{16}$ the length of the copepods was inversely related to the temperature. This caused relatively small sized copepods in summer. ${ }^{16}$ Piyasiri ${ }^{22}$ found similar results for a tropical Calanoid, Phyllodiaptomus annae, which suggests that the body sizes of the zooplankton are smaller in tropical waters, compared to that of temperate waters.

$D$. lumholtzi found in the present study was the largest Cladocera of the reservoir with a mean length of $1.38 \mathrm{~mm} \mathrm{SD} \pm 0.12$ in the range of 1.98 to $2.34 \mathrm{~mm}$. According to Brooks, ${ }^{23}$ the species found in the temperate zones reached body 
lengths of 2.5 to $5.0 \mathrm{~mm}$. The mean body length recorded for cyclopoids in the Kotmale reservoir was well within the length range recorded by Fernando. ${ }^{14}$ However C. cornuta found in the Kotmale reservoir was fairly big ( 0.36 to $0.84 \mathrm{~mm}$ ) compared to body lengths recorded for $C$. cornuta in the Netherlands by Zaret ${ }^{20}$ and the body lengths $(0.32-0.34 \mathrm{~mm})$ recorded by Rajapakse \& Fernando ${ }^{15}$ in Sri Lanka. When the Kotmale reservoir was covered with a thick bloom of M. aeruginosa in Sept. to Dec. 1991, C. cornuta with smaller body size dominated the zooplankton population. There is no scientific explanation for this. However a similar situation has been recorded in a sub tropical lake in South Africa. ${ }^{24}$

In the present investigation different zooplankton types have shown differences in their vertical distribution pattern (Fig.4). However most of the zooplankton experienced high densities from 20 to $40 \mathrm{~m}$ region. At the St1, when the water level dropped during drought and when the power generation was limited, the densities of most of the zooplankton decreased with increasing depth. Piyasiri \& Jayakody ${ }^{6}$ found similar patterns for the Victoria reservoir. Accumulation of most zooplankton types in the water column from $20 \mathrm{~m}$ to $40 \mathrm{~m}$ indicates that they may have found the thermocline established ${ }^{11}$ at $20 \mathrm{~m}$ depth as a barrier for upward migration. Welch ${ }^{25}$ described a similar situation for many other water bodies. However it is difficult to generalize the vertical distribution of zooplankton as a whole. ${ }^{25}$ The controlling circumstances being so involved and so variable a general statement is not possible.

As described by Welch, ${ }^{25}$ the distribution behaviour of zooplankton may be very different in different kinds of water. It may be influenced by combined factors such as (i) physico chemical stratification, (ii) light, (iii) food (iv) dissolved oxygen (v) temperature (vi) wind, (vii) gravity and (viii) age of individuals of a species. The Kotmale reservoir is thermally stratified ${ }^{11}$ and dissolved oxygen is low in the deeper hypolimnion compared to the epilimnetic region. These factors together with high density of phytoplankton and better light conditions might have influenced high abundance of certain zooplankton types in the surface water layers of the Kotmale reservoir.

\section{References}

1. Fernando C.H. (1980). The fresh water zooplankton of Sri Lanka with a discussion of tropical fresh water zooplankton composition. Internationale Revue der gesamten Hydrobiologie 65: 85-125.

2. Fernando C.H. (1980). The species and size composition of tropical fresh water zooplankton with special reference to the oriental region (South East Asia). Internationale Revue der gesamten Hydrobiologie 65: 411- 426. 
3. Fernando C.H. \& de Silva S.S. (1984). Man made lakes; an ancient heritage and modern biological resource. In: Ecology and biogeography of Sri Lanka (Ed. C.H. Fernando) pp. 431 - 451 Dr W. Junk, The Hague.

4. Duncan A. (1983). The composition, density and distribution of the zooplankton in Parakrama Samudra. In: Limnology of Parakrama Samudra - Sri Lanka: a case study of an ancient man made lake in the tropics. Developments in Hydrobiology. (Ed. F. Schiemer) pp. 85-94. Dr W. Junk, The Hague.

5. Fernando C.H. \& Rajapakse R. (1983). Some remarks on long term and seasonal changes in the zooplankton of Parakrama Samudra. In : Limnology of Parakrama Samudra - Sri Lanka: a case study of an ancient man made lake in the tropics. Developments in Hydrobiology. (Ed. F. Schiemer) pp.77 - 84. Dr W Junk, The Hague,

6. Piyasiri S. \& Jayakody J.K.U. (1991). Ecology of zooplankton at Victoria reservoir in Sri Lanka; composition and population structure of zooplankton. Verhhandlungen Internationale Vereinigung Limnologie 24: 1430 -1435.

7. Chandrananda W.P.N. \& Piyasiri S. (1992). Seasonal, diurnal and vertical distribution patterns of cyclopoids in Kotmale reservoir. Vidyodaya Journal of Science 4(1): 179 - 189.

8. Pathmalal M.M. \& Piyasiri S. (1994). Composition and population dynamics of zooplankton in Randenigala reservoir, Sri Lanka. Proceedings Sri Lanka Association for the Advancement of Science, Part 1 (Abstracts), p. 171.

9. Hettiarachchi H.A.A. \& Piyasiri S. (1994). The composition and population dynamics of plankton in Rantambe reservoir, Sri Lanka. Proceedings Sri Lanka Association for the Advancement of Science, Part 1 (Abstracts), p. 173.

10. Fernando Y.D.N. \& Piyasiri S. (1994). Composition and distribution of plankton and diurnal migratory patterns of zooplankton in Victoria reservoir, Sri Lanka Proceedings Sri Lanka Association for the Advancement of Science, Part 1 (Abstracts), p. 172

11. Piyasiri Swarna (1991): Limnology project at Mahaweli reservoirs: 1 . Some physical properties of Kotmale, Victoria and Randenigala reservoirs. Vidyodaya Journal of Science 3(1): 45-61. 
12. Piyasiri S. (1995). Eutrophication and algal bloom problem in Kotmale reservoir, Sri Lanka. In: Tropical limnology Vol II (Eds. K. H. Timotius \& Goltenboth) pp. 161-169. Faculty of Science and Mathematics, Satya Wacana Christian University, Salatiga, Indonesia.

13. Streble H. \& Krauter D. (1981). Das Leben im Wasser tropfen. Mikroflora and Mikrofauna des Suswassers.pp. 32-63,79-314. Kosmos Geselshaft der Naturfreunde Franckh'sche Verhandlung W Keller \& Co., Stutgart.

14. Fernando C.H. (1979). The fresh water zooplankton of Sri Lanka with a discussion of tropical fresh water zooplankton composition. Bulletin Fisheries Research Station, Sri Lanka 29: 11-54.

15. Rajapakse R. \& Fernando C.H. (1982). The Cladocera of Sri Lanka (Ceylon), with remarks on some species. Hydrobiologia 94: 49-69.

16. Vijverberg J. (1977). Population structure, life histories and abundance of copepods in Tjeukemeer. The Netherlands Fresh Water Biology 7: 579-597.

17. Costa H.H. \& de Silva S. S. (1969). Hydrobiology of Colombo (Beira) Lake, I. Diurnal variations in temperature, hydrochemical factors and zooplankton. Bulletin Fisheries Research Station, Ceylon 20 (2): 141-49.

18. Zaret T.M. (1969). Predation - balanced polymorphism of Ceriodaphnia cornuta sars. Limnology and Oceanography 1: 301-303.

19. Zaret T.M. (1972). Predator prey interaction in a tropical lacustrine ecosystem. Ecology 53: $248-257$

20. Zaret T. (1980). Predation and fresh water communities. Yale Univ. Press, New Haven, Connecticut, U .S. A.

21. Vidal J. (1980). Physioecology of zooplankton. I. Effects of phytoplankton concentration, temperature and body size on the growth rate of Calanus pacificus and Pseudocalanus sp. Marine Biology 56: 111-134.

22. Piyasiri S. (1984). Der Einfluss von Temperatur und Futterkonzentration auf Wachstum und Entwicklung von Aqei Calanoiden Copepoden Phyllodiaptomus annae (Apstein) und Arctodiaptomus spinosus (Daday) $P h D$ thesis Univ of Vienna 82-89.

23. Brooks J. L (1963). Cladocera in freshwater biology. (Ed. W. T. Edmonson) pp. 587 - 656. John Wiley, New York. 
24. Zohary T. \& Robarts R D. (1989). Diurnal mixed layers and the long-term dominance of Microcystis aeruginosa. Journal of Plankton Research 11 (1): 25-48.

25. Welch P.S. (1963). Limnology pp. 238-245. Mc Graw-Hill Book Company, New York. 